\title{
Implementation of Waste Management Model through Bank Official Environmental Waste District North Barito
}

\author{
Meidiyanti Arusbi*, Budi Suryadi, Jamaluddin \\ Master Program of Government Science, Lambung Mangkurat University, Banjarmasin, Indonesia
}

\author{
DOI: $10.36348 /$ sjef.2019.v03i11.010 $\quad$ | Received: 09.11.2019| Accepted: 16.11 .2019 | Published: 19.11 .2019 \\ *Corresponding author: Meidiyanti Arusbi
}

\section{Abstract}

Garbage Bank Model Environment Agency Barito Utara is the only bank in the garbage under the supervision of the Environment Agency of North Barito regency. Garbage Bank was established as one form of implementation of the program of Jakstrada (Regional Strategy Policy) established by the Local Government and is a derivative of Jakstranas (National Strategy Policy) launched by the Central Government to become one of the solutions to cope with the growing pile of trash. The implementation process in running the management of the waste bank is very influential in the success of a policy. The method used was the descriptive method by using the theory of policy implementation George C. Edward III, where the implementation level four factors influence, namely: communication, resource, disposition, and bureaucratic structure. The study concluded that the Bank's policy implementation Environment Agency Waste North Barito regency is still not optimal when only implemented in the communication aspect, disposition, and bureaucratic structure. Limiting factor in the implementation of Waste Bank DLH Kab. This diaper is of a factor is the lack of executive resources (staff) garbage bank manager, a minimal budget and supporting facilities such as waste transportation expedition fleet were sold to collectors outside the city.

Keywords: Bank of garbage, trash, and implementation of policies.

Copyright @ 2019: This is an open-access article distributed under the terms of the Creative Commons Attribution license which permits unrestricted use, distribution, and reproduction in any medium for non-commercial use (NonCommercial, or CC-BY-NC) provided the original author and source are credited.

\section{PRELIMINARY}

Law No. 18 of 2008 on Waste Management defines that garbage is the rest of the daily activities of human and/or natural processes in the solid form, the form of household waste, household-like waste, and specific waste. Sources of waste derived from garbage are generated by any person and/or by the natural process produced waste. Household waste is derived from daily activities in the household, excluding specific feces and garbage. Household-like waste from regions commercial, Industrial areas, special areas, social facilities, public facilities, and/or other facilities. While specific waste is waste that due to nature, concentration, and/or volume require special handling [1].

In North Barito regency alone, especially in the district town of Muara Teweh Teweh middle have produced waste a population of $31,507 \mathrm{~kg} / \mathrm{day}$, or if divided by the total population in the service area, amounting to 33,091 inhabitants the importance of waste production average of $0.95 \mathrm{~kg} /$ person/day. During this time the people in the town of Muara Teweh only perform garbage collection in their homes without sorting, then the garbage is taken out by a garbage collector (garbage worker) after the handymancollectorThe garbage carrying garbage to the TPS (Temporary Storage Place), but much of the household garbage disposed by the community without going through the garbage collector. Then the garbage that is in the polling station by car hauls garbage in garbage dumped into a landfill.

Guided by the Regulation of the Minister of Environment of the Republic of Indonesia Number 13 the Year 2012 on Guidelines Reduce, Reuse and Recycle Through Garbage Bank, then in 2016, the Environment Agency of North Barito district set up a garbage bank. Bank aims to accommodate garbage bins that have economic value that can be recycled into marketable goods. The existence of this waste banks are beginning to build the community in waste management from waste sorting, recycling bins, until the use of waste because the waste has a good enough selling point so that environmentally sound waste management could be a new culture in Indonesia [2].

Waste bank policy implementation in North Barito regency is environmentally sound development programs to overcome problem garbage constantly 
increasing. With the hope of freeing the Indonesian Government's target of 2025. Implementation trash bins bank is appropriate instructions from Barito Utara Bupati Number: 960990 / BLH / XII / 2015 dated December 30, 2015, that instructs the public to utilize the waste bank. Bank litter as one of the breakthroughs of the Government to improve the community's active role to tackle the problem garbage is continuous and sustainable. The mechanism of the garbage bank starts from sorting of waste from their own homes, depositing, weighing, recording to be reported in the form of passbook and bookkeeping clear the garbage bank manager. The implementation of waste banks is expected to provide added value or economic value of waste. This article aims to describe the implementation of the Bank's policies Garbage models Environment Agency North Barito regency. So it can be used as a comprehensive study regarding the problem of waste management schemes.

\section{RESEARCH METHODS}

A qualitative approach with descriptive methods is used to describe the implementation of the waste bank DLH models in North Barito regency. The qualitative research method is a method that is based on the philosophy of postpositivism. In the natural object of researchers is a key instrument [3]. Qualitative research is research that aims to understand the phenomenon of what is experienced by the subject of the study such as behavior, perception, motivation, action and other holistically and by way of description in the form of words and language, in a specific context naturally and by utilizing various natural methods. This research was conducted at the Bank Trash Model Environment Agency of North Barito district in the town of Muara Teweh. The data source is divided into two, namely.

Selection of informants in this study conducted by purposive sampling, ie selecting informants considered the most informed and experienced for research purposes. Informants among others; DLH head Barito Utara, Chairman of the Bank Trash DLH North Barito district, seven people from Garbage Bank manager, and two of the Bank's customer DLH Waste District. Barito Utara. Data collection technique; 1) interviews through the direct interaction approach. 2) Observation of the previously known phenomenon of knowledge and ideas for the fulfillment of information, and 3) documentation of the recording of the images, video, and sound to obtain information for research [4]. Analysis of the data to segment based on nature, types, and characteristics to ease the use of the data through three steps;

\section{RESULTS AND DISCUSSION}

The policy is a basic concept that contains the basic principles or in an activity plan work and how to act in leadership. There are several theories regarding the proposed policy that is understood as a provision that sets out principles to direct action created in a planned and consistent in achieving specific objectives [5]. The government's policy is defined as the power allocation value for society as a whole. Therefore, government authority covering the entire life of society. Reality garbage bank policy implementation model of DLH's Barito Utara researchers used model implementations used by George C. Edward III named the model of implementation of public policy in terms of Direct and Indirect Impact on Implementation. This model has four variables in it, namely; communication, resources, disposition and bureaucratic structure [2].

\section{COMMUNICATION}

Strip the spread of good communication is essentially produces a good result also in the implementation of a settlement of the problem, as well as waste management through a waste bank in North Barito regency especially the city of Muara Teweh managed directly by BLH North Barito regency. In an organization, communication is a process that is complex, ambiguous and inaccurate which should be understood by the implementor (executor). Differences in resources can lead to the interpretation that various and different results in communication. For effective implementation of commitment required a responsibility to implement policies to a lack of compatibility of the results to be obtained. In communication, skills became an important part so that the message obtained undistorted information or the occurrence of miscommunication. Because of the nonfulfillment of the communications to the implementers can affect the results of policy implementation [6].

One difficulty in the management is the practice managed by two dynasties, namely the General Development (PU) and the Environment Agency (DLH). The Public Works Department is the agency that builds, all existing operational. This is because the system in the City of PU, then ideally not regulate solid waste. Solid Waste remains under the governance line of the Environment Agency. The subject is based on Law No. 23 that set it all affairs Environment DLH managed garbage. City Planning DPUPR field who manage waste on a large scale or urban. Where should the City Planning Division attach to the Environment Agency of North Barito regency? DLH North Barito district "only" tasked with the establishment of independent waste management institutions such as banks garbage.

In the context of the implementation of the policy implementation of the waste bank, the Environment Agency of North Barito regency always establishes good communication, accurately and clearly to the implementation (executive/subordinate) directly involved in the achievement of the policy objectives of a program as expected. Generally, all employees at the Environment Agency of North Barito district itself obliged by to support the bank's policy of this garbage. 
Especially on junk bank managers themselves that they perform their respective functions following the duties and obligations in the work. Policy predetermined program aims to reduce the problem of waste in the environment onset district. North Barito and the demands of the eco-friendly establishment.

The presence of the active role of the implementer is desirable to realize good governance and solid waste as expected. Because it takes a clear understanding of the communication system that is run to run effectively to all implementer. It is for the creation of accurate, straightforward and appropriate for the implementer. Vice versa, less than optimal communication impact a lack of understanding for the implementer, in this case, it is a waste bank clerk.

In an environment of Waste Bank managers, each personally understands and fulfills the task given. This is because information and communication are very run well. Information is a very important resource for the implementer of the function and scope of responsibilities. Environmental Office North Barito regency itself in waste management never fails to continue to coordinate with the City Planning Division DPUPR.

\section{Resource}

The theory put forward by Edward III on the importance of resources for the realization of good policy implementation [7, 8]. He said there are several indicators used in influencing viewpoints success policy implementation, which consists of:

\section{Staff}

Staff or employee (street-level bureaucrats) is the main resource that is needed in the implementation of the policy. Failure that sometimes occurs in an implementation of the policy, one of which is caused by the human resources as the implementer of inadequate or low enough level of competence in the field, Increasing the number of staff or employees is not enough to resolve problems in the implementation of policies, but more than that, with skilled and capable staff who preferred to be empowered and sufficient. DLH number of employees in North Barito regency is 75 people. However, the manager of Waste Bank DLH North Barito regency only amounted to 12 people. This means that only $15 \%$ of the total employees in DLH districts North Barito who become managers. Many factors cause, in addition to insufficient budget for incentive payments (honorarium) also technical employees often do their fieldwork making it impossible to have a more functional work that takes quite a lot like a garbage bank.

Human resources are owned by DLH Waste Bank Model in North Barito district overlook to the availability of staff implementing aspects of the program policies established which administrative personnel and personnel transport/garbage pickup. From observations and interview informants regarding the availability of adequate human resources, this can allow a good bank services garbage and waste transportation residential society made by officers carrying garbage with effective management of the bank. Human resources are the main capital point to motivate the realization of the quality of solid waste services in the maximum utilization of the waste bank. Keep in mind also that the number of executive staff always has a positive impact on the implementation of a policy or program. The statement stressed that while the number of staff (administrators/members) held to encourage the birth of a good implementation.

\section{Information}

In implementing the program policies, information has two forms, namely the information related to how the policy was implemented and the information related to the compliance of the executive staff/employees of the laws and regulations that have been established. Information related to carrying out the policy means that the policy implementers should be clear about what information, how and what should be their function. Clarity of information can greatly affect performance. Information regarding compliance data from the executor of the laws and regulations that have been established to give the sense that how the compliance of implementing a policy that has been set. Business Garbage Bank is giving information clear and easy to understand to people who sometimes have problems. This is because not all people understand and comply with the rules that apply.

\section{Authority}

Waste Management Bank in North Barito regency is given the authority to DLH North Barito district through a leading sector on Waste and Waste Management Division B3. This is following the duties (job description) contained in Barito Utara Bupati Regulation No. 5 of 2017 on Duties and Job Description Position in North Barito regency DLH. In performing the duties assigned a bank manager SK (Letter) Head DLH Barito Utara District Officer Waste Bank of North Barito regency DLH. SK stipulated in the arrangement of the names of officers and any authority that should be implemented. Both of Trustees Chairman Garbage Bank to Bank Trash, or from Garbage Bank chairman to executive.

\section{Amenities}

Next resource that infrastructure bank-owned garbage. Facilities and infrastructure is a means of supporting the success of a process conducted in public service. Facilities owned by the bank of garbage models LH District North Barito sufficient. Permanent buildings and a yard large enough garage Bank District Environmental Office. North Barito has 2 pieces of the building, which is one fruit of the main building as the secretariat of Waste Bank and one of the buildings open 
to the landfill and composting. Besides, there are other facilities in the building;

1) meubelair; Tables, chairs and cabinets for customer service

2) Motorcycle Three (Nozomi) and Mobil Box

3) scales

4) Sieving machines, Conveyor (enumerator compost material) and Mixer compost

The availability of facilities and infrastructure to implement a policy is extremely important. Ultimately affect the performance of the executor. Lack of fleet today is still an obstacle for a bank officer garbage in garbage pickup optimizing the house residents. Equipment, infrastructure or facility can be a reason for the failure of the implementation of the policy if it is not met. Lack of adequate infrastructure can affect the successful implementation of policies and ultimately negatively affect the goals/objectives of the program. If the means of managing waste banks supported with adequate facilities ie, as a means of the waste transport fleet and other equipment the service to several areas in the city district of Muara Teweh easily accessible and served well and quickly.

\section{Disposition}

Disposition is defined as the tendency of the attitude of the implementers. An important indicator, because it deals with how the response or attitude implementers in developing performance. Effective implementation of a program of integrity influenced the administrators. All of it must have a strong motivation and support along with a great desire to the implementation of good policy implementation following the initial decision. If the executive does not have the motivation or encouragement to participate in the success of a policy implementation so far short of expectations it could be done well and on target. The lack of intensity of this disposition will fail in policy implementation. This can be seen through the effect of a tendency.

The attitude held by the executive program of this garbage bank policy with commitment and integrity. Compactness, as well as mutual respect and help, is also good coordination among the garbage bank managers are highly demanded in implementing a policy that all the expectations and objectives are achieved. The garbage bank manager is very aware and reliable in performing their duties and functions in implementing the obligations as the manager of the waste bank. The tendency occurred in the management of Waste Bank DLH North Barito district regarding the availability of financial or operational budget. When executing the performance required to provide the best, especially for community satisfaction is inversely proportional to the availability of budgets operational owned bank Environment Department Waste District. Barito Utara.
The commitment of local governments to finance the waste management of solid waste to reduce the budget set forth by the District. North Barito through DPA PD DLH North Barito district annually. It is undeniable that the strong budget is the most influencing factor in a ministry. Each program within an organization requires budget support in carrying out the work at the same time operationalize the implementation or monitoring of all programs to sustainability. The availability budget in the management of waste banks is very small. For banks operating expenses partially garbage obtained from the difference of the balance of junk sales to collectors in London. Partly from the budget available in North Barito regency DPA DLH corresponding fiscal year. However, the low budget allocated to the obstacles in the bank's operations garbage. In the first fiscal year can only be allocated Rp. 38.7 million, - only. Where $88 \%$ are for honorarium payment bank clerk and the clerk composting bins and the remaining $12 \%$ of spending on goods and services.

The small budget available for processing waste, in particular, to finance the operations of the Bank Trash. Think this was in fact due to the impact of Act No. 23 of 2014 on Regional Government, where there stated that that the Environment Agency is to be obligatory and non-basic services, which ultimately affect the budget in the area. On the other hand, not only the availability of waste banks operating budget be small but the funds for waste management and dissemination of the existence and benefits of any bank very little trash. This implies a lack of public awareness to contribute to the strategic policy of the Regional Head. The constraints emerging trends that are still going on in the management of Waste Bank DLH North Barito regency is about incentives and availability of household amenities (kitchen) for managers. The low budget allocation for garbage bank operations coupled with incentive distribution (outside the official stipulations according to SK honorarium) into social inequality. The subject is due to the heavy-duty but gets the same par with a lighter officer job.

\section{Bureaucratic structure}

The organizational structure in charge of implementing the policy has a major influence on policy implementation. The bureaucratic structure, two important things that can influence its implementation, namely SOP (Standard Operating Procedure) comes from within the organization and fragmentation that comes from outside the organization. Bureaucratic structure in North Barito regency DLH very clear. The technical field of waste management lies in the field of waste management and B3. The authority waste management area is only enabled for the Department of Public Works and Spatial Planning, even if we trace back the Law No. 23 of the Environment, it is clear that for environmental management (therein including waste management, sanitation, and other costs associated with 
the environment) is the functions of the Environment Agency. However, this condition has always been not changed, despite the nomenclature has changed since the beginning of 2017, everything returns to the Top Management authority which makes the policy and decides the end of the district. North Barito waste management on a large scale managed by DPUPR Kab. Barito Utara. And DLH Kab. North Barito "only" manages internal garbage such as through the waste bank.

First, the Bank Waste management, waste management, and B3 have established SOP (Standard Operating Procedure) clear Garbage Bank for implementation of the plan. This is to facilitate the executor to run functions and their respective duties. The SOP is set so that there is uniformity in the line of duty in the bureaucracy. SOP clarity in the implementation of a policy, facilitate the implementer to know, understand, and explore and implement the substance of the results to be achieved. The purpose of the SOP so that the staff/implementers to maintain consistency and performance levels of staff/implementers or teams within an organization or work unit, to clarify the flow of duties, authority and responsibility.

Second, Fragmentation (the spread of responsibility) is the spread of responsibility for policy areas among different organizational units by implementing the waste management policy implementation and management of Waste Bank DLH North Barito regency. Fragmentation for waste management in the district. North Barito, then back again we look back their waste management given to 2 (two agencies), namely DPUPR and DLH North Barito regency. But the clarity of responsibility already contained in their respective duties. That DPUPR through City Planning Division in charge of managing solid waste urban scale (large) and DLH North Barito district is in charge of managing internal garbage through the garbage bank. Fragmentation affects the planning process that has been set in the planning phase of implementation of waste management policy through garbage bank. In the bureaucratic structures, no problems were encountered.

\section{CONCLUSION}

Bank garbage collection bins is a concept that has undergone sorting first and has appropriate management of banking but that is saved is not money but junk money's worth. Bank of garbage is one strategy to implement the 3R (Recycle, Reuse, Reduce) in community management mechanism from the community level. Bank garbage conceived as a solution for the management of household waste. Concerning the North Barito district government issued a policy for bank made trash. Garbage Bank Model Environment Agency of North Barito district only waste bank under the supervision of the Environment Agency of North Barito regency. The Bank's policy implementation Environment Agency Waste North Barito regency is not optimal. The subject is implementation only in the aspect of communication, disposition, and bureaucratic structures. Limiting factor in the implementation of Waste Bank DLH Kab. This diaper is of a factor is the lack of executive resources (staff) garbage bank manager, a minimal budget and supporting facilities such as waste transportation expedition fleet were sold to collectors outside the city.

\section{REFERENCES}

1. Aryenti, A. (2011). Peningkatan Peranserta Masyarakat Melalui Gerakan Menabung pada Bank Sampah Di Kelurahan Babakan Surabaya, Kiaracondong Bandung. Jurnal Permukiman, 6(1), 40-46.

2. Abidin, S. Z. (2012). Kebijakan Publik. Jakarta: Salemba Humanika.

3. Afrizal. (2014). Metode penelitian kualitatif: sebuah upaya mendukung penggunaan penelitian kualitatif dalam berbagai disiplin ilmu. PT RajaGrafindo Persada.

4. Mulyana, D. (2004). Metode penelitian kualitatif: paradigma baru Ilmu Komunikasi dan Ilmu Sosial lainnya. Bandung: Remaja Rosdakarya.

5. Solichin, A. W. (2008). Analisis Kebijakan: Dari Formulasi ke Implementasi Kebijakan Negara Edisi Kedua. Jakarta: Bumi Aksara.

6. Dunn, W. N. (1999). Pengantar Analisis Kebijakan Publik. Yogyakarta: Gajah Mada University Press.

7. Suharto, E. (2005). Membangun Masyarakat Memberdayakan Rakyat. Bandung: PT. Refika Aditama.

8. Subarsono. (2005). Analisis Kebijakan Publik, Konsep, Teori dan Aplikasi. Yogyakarta: Penerbit Pustaka Belajar. 